Annals of Warsaw University of Life Sciences - SGGW

Horticulture and Landscape Architecture No 39, 2018: 17-25

(Ann. Warsaw Univ. of Life Sci. - SGGW, Horticult. Landsc. Architect. 39, 2018)

DOI 10.22630/AHLA.2018.39.2

\title{
Disturbed, restored and novel ecosystems - Concepts and practices challenging landscape planning, design and management in the 21st century
}

\author{
PAULO FARINHA-MARQUES, CLÁUDIA FERNANDES, CATARINA \\ TEIXEIRA \\ Faculty of Sciences, University of Porto
}

\begin{abstract}
Disturbed, restored and novel ecosystems - Concepts and practices challenging landscape planning, design and management in the 21st century. Since the industrial revolution of the 18th century the human population has been quickly expanding (aprox. 7.5 billion people in 2017 according to Worldmeters.info), deeply changing all the ecosystems of the Earth and increasingly concentrating in cities (54\% in 2014 according to World Health Organization) generating vast metropolitan areas. Such huge numbers impose a fast change on the metabolism of the biosphere, resulting in deforestation, natural resource depletion, pollution, global warming, desertification, urban sprawl and biodiversity loss. The results show large tracts of bare, dull and poor landscapes, incapable of nourishing their populations, forcing them to migrate, into starvation or to warfare. Conservation measures have focused on remote or less populated areas, particularly those with remaining natural quality, high scenic beauty, high profile wildlife species, or a pre-industrial rural character. Few restoration strategies have also been implemented, particularly in developed countries, to rescue degraded landscapes, resulting in a variety of multi-scale green structures such as nature reserves, green belts, green corridors, greenways, blue and green infrastructures, heritage cultural sites and landscapes and urban green spaces. Modern human fluxes have moved species across the oceans and continents, increasing sudden colonisations and an immediate change of local ecosystems that have evolved during long periods of time. Recently some of these new assemblages of species acquired the designation of novel ecosystems: human induced, selfsustainable assemblages of "exotic" and autoch-
\end{abstract}

thonous species in particular biophysical contexts, with the tendency for the "exotics" to dominate and override the indigenous. These new ecosystems apparently have no parallel in the natural environment and are becoming the dominant habitats on the face of the Earth. These overwhelming issues require a fresh look to develop combined and systematic approaches to resolve the conservation of long term evolving natural ecosystems, the sustainability of human dependent ecosystems and the integration novel ecosystems with old ecosystems. Everyone's commitment is valuable to share ideas and actions, integrating change and guaranteeing high levels of biodiversity, natural resource availability and natural space accessibility for the future. Our global awareness must activate local planning, design and management programmes and practices to exercise knowledge, tackle poverty and enhance the quality and dignity of life. This is a matter of life and death and... LIFE MATTERS!

Key words: overpopulation, new ecosystems, new landscapes, global awareness, local action

\section{FUTURE CHALLENGES TO OUR PLANET}

The 21 st century has just started and it has already permanently marked the Earth's history. Mankind has accomplished several breakthrough findings but, on the other hand, human evolution has, as well, led us to serious future chal- 
lenges. Our planet is experiencing major and unprecedented transformations at an accelerated rate (Donihue and Lambert 2015). Human economic activities, combined with an intense process of urbanization, have transformed irreversibly the world's landscapes, introducing a wide range of new ecological processes that have transformed deeply the Earth's system (Ellis and Haff 2009). It is no longer possible to explain the globe's ecological patterns and processes without considering the dominating human activities (Ellis 2015). In fact, the changes are already so profound and measurable that it is even possible to assume the emergence of a new "geologic" Era: the Anthropocene (Ellis 2011, 2015).

The world's population is constantly growing, leading to an overpopulated state that is mainly concentrated in urban settlements. Although urban areas occupy only a small portion of the Earth's surface (about $3 \%$ ), they are inhabited by more than a half of the world's population (Millennium Ecosystem Assessment 2005). In 1900 only $10 \%$ of the world's population lived in cities (Grimm et al. 2008). More updated data reveals that in 2016 approximately $55 \%$ of the global population lived in urban settlements and $23 \%$ lived in a city with at least 1 million inhabitants (United Nations Population Division 2016). These numbers are overwhelming and are expected to grow fast very soon, raising awareness about what might be the consequences.

The rapid urbanization processes over the last decades represents numerous shifts in the urban dynamics: modifications in the land use, the removal of the vegetation (particularly impactful for large woody species), the spread of im- pervious surfaces, pollution and contamination, the alteration of hydrologic and biogeochemical cycles, and the introduction and dispersion of exotic plant and animal species (Kowarik 2011). These sets of events have triggered major changes around the globe, threatening people's quality of life and causing huge negative impacts on a very worrying scale, such as natural resources depletion, deforestation, global warming and rising of the sea levels, the fragmentation of habitats, biodiversity loss, degradation of the ecosystems and desertification.

The list is endless. Every corner of the planet has already experienced some level of disruption due to human activities (Del Tredici 2007), and the continuity of this situation will certainly result in large tracts of bare, dull and poor landscapes, incapable of nourishing their populations and forcing humans to migrate and escape from starvation and, eventually, war.

\section{THE URGENT NEED TO ACT}

Although scientific data have been confirming over the years the alarming fate of the planet (if we do not change our actions), it seems that the economic and political interests of the powerful groups in charge are prevailing when decisions are made. Moreover, the actions of these powerful economic interests are provoking consequences worldwide and not just locally.

In the speech "Racing to the Precipice: Global Climate, Political Climate", Noam Chomsky debates these issues and alerts us to the need of acting urgently, because "we might pass a point of no re- 
turn when the damage that we've done is simply uncontrollable, irreversible, and it might not be far off' (Chomsky 2017). He presents several data about the changes our planet is experiencing, proving that the danger is real.

For the last years, the Doomsday Clock of the Bulletin of the Atomic Scientists is getting closer to midnight, which means that we are closer to a global disaster. The main reasons for this are the threat of nuclear war and the failure to deal with climate change. The Clock is now (2017) pointing to two and a half minutes to midnight and that is the closest it has been to midnight since 1953 (during the Cold War). "In 2017, we find the danger to be even greater, the need for action more urgent. It is two and a half minutes to midnight, the Clock is ticking, global danger looms. Wise public officials should act immediately, guiding humanity away from the brink. If they do not, wise citizens must step forward and lead the way" (Bulletin of the Atomic Scientists 2017). We should not need more warnings. Future generations will be handling a very difficult situation if nothing is done.

\section{LANDSCAPE AND BIODIVERSITY CONSERVATION}

Against such an alarming scenario the challenges to landscape conservation and management are rising. We must manage efficiently our territory and our resources and create the necessary tools for a more resilient future. Otherwise, the consequences will be rather severe for human communities, particularly those already affected by low societal organization and poverty.
Cities are often located in biodiversity spots, recurrently creating conflicts with natural values and associated conservation aims (Kowarik 2011). The remaining and the human created urban green spaces (e.g. parks, gardens, woodlands, street trees, etc.) act as a compensation for the loss of biophysical values by providing a multitude of ecosystem services: environmental, economic, social and aesthetical services (Millennium Ecosystem Assessment 2005).

Landscape planning, design and management can play an important role in providing these multifunctional green spaces in the city, close to where people live, work, cultivate, conserve natural resources, recreate and contemplate. These spaces can improve the urban ecosystem and allow opportunities to people to make contact with nature more often (Miller and Hobbs 2002, Colléony et al. 2017) and be aware of its irreplaceable value. Unfortunately, unless people realize and understand the importance of these spaces in their life, it is very difficult to allocate funds to either conserve or develop them.

According to the contemporary philosopher Byung-Chul Han in his book entitled "The Burnout Society" (2010), modern human communities live obsessed with productivity, efficiency and profit, generating hyperactive individuals that have difficulty in finding time to rest, to reflect and to indulge themselves in leisureliness. This also leads to a decrease in opportunities to experience nature (Soga and Gaston 2016). In the city, people are constantly exposed to several stimuli and sources of information that demand great levels of attention and end up causing stress and fatigue (Kaplan 
1995); several studies have proved that the contact with nature influences our well-being, reduces headaches, stress and other health problems and improves restoration and a positive attitude (Kuo 2003, Velarde et al. 2007, Bratman et al. 2015). Barriers between people and nature affect negatively human wellbeing and induce nature disconnected attitudes. This is particularly relevant regarding children, who may never experience nature during their childhood and misunderstand the benefits of that experience, contributing to nature-deficit disorders caused by the growing gap between nature and humanity (Louv 2010). Children devalue nature by valuing other indoor activities, namely entertainment media, computers and video games. The design of school yards should as well be a priority to minimize these effects and provide opportunities to experience nature and learn about/with it. Being disconnected from nature may, eventually, lead a person to assume that such contact is unnecessary, also affecting the way people perceive, understand and experience ecosystems and the importance of landscape conservation (Soga and Gaston 2016, Colléony et al. 2017); this can lead to over-simplified ways of thinking, low critical judgment of the processes of life, poor evaluation, and consequently inappropriate decision making; poor lives, lead to poor landscapes.

Although Byung-Chul Han (2010) characterizes modern society as hyperactive in all sorts of activities, in what concerns politics he thinks people tend to be hyper passive. This is worrying, particularly when it concerns ecological and environmental issues, despite the rise of many environmental organizations in re- cent years. It seems that there is still not enough collective consciousness about these matters and unless they are widely perceived and experience nature in a deeper way, it will be more difficult to overcome problems raised by the environmental crisis.

Some measures have already been implemented, but there is still a long way to go. The portion of the living Earth that has received positive intervention is a tiny fraction when compared with the amount of degraded land left behind. Conservation measures have focused on remote or less populated areas, places with remaining natural quality, high scenic beauty, historic value, landscapes with a pre-industrial rural character and high-profile wildlife species.

Few restoration strategies have been accomplished in order to rescue degraded landscapes, such as artificial breeding programs to rescue one of the most endangered species of wild cats, the Iberian Lynx. A variety of multi-scale policies and projects that promote large scale green structures have also been created: nature reserves (for more pristine remaining natural environments), green belts (to control the expansion of the dense urban core), green corridors (to emphasize ecological connectivity) and greenways (to emphasize social connectivity).

In this quest, everyone's commitment is valuable to share ideas and actions, integrating change and guaranteeing high levels of biodiversity, natural resource availability and natural space accessibility for the future. Our global awareness must activate local planning, and design and management programs and practices to exercise knowledge, tackle poverty 
and enhance quality and the dignity of life.

It is very possible to participate and share in the solutions, and some people have made the difference. The example of Yakuba Sawadogo, from northern Burkina Faso, is very inspiring. He rescued his farm from the desert using traditional techniques regarding water conservation, organic matter fertilization, planting resilient native species and overall shaping the cultivated ground in a conserving way. On the other side of the Atlantic, in a degraded farmland area between Minas Gerais e Espírito Santo, Brazil, there is also a remarkable example of a large-scale landscape restoration project through the use of native plant species; this project is due to the vision of Leila and Sebastião Salgado, who since 1998 have created "Instituto Terra" - which is dedicated to rescuing impoverished land and changing it for richer forested natural habitats. In 12 years, they turned barren and eroded land into a multilayered woodland on their family farmstead and are now influencing the restoration of 7,000 hectares of Atlantic Rain Forest.

\section{A NEW NATURE IN THE CITY}

As stated before, the urbanization process can have a massive impact on the biodiversity loss and habitats' fragmentation. On the other hand, urban transformations can also provide several opportunities. A study carried out by Kühn et al. (2004), which compared floristic assemblages of rural and urban areas in Germany, discovered that cities can accommodate high numbers of species, including rare and endangered native species. And, even though cities have high percentages of alien/introduced species, when compared to rural areas they can be richer also in native plant species (Kowarik 2011). This floristic heterogeneity in the urban areas is being increasingly debated among researchers, originating new concepts to define the "new nature" of the city. Modern human fluxes have moved species across the oceans and continents, causing sudden colonization and the immediate transformation of local ecosystems that have evolved during long periods of time. The processes in the origin of the world's economic globalization have also resulted in the globalization of the environment (Del Tredici 2007). New assemblages of exotic and autochthonous species have emerged, acquiring the designation of novel ecosystems. Novel ecosystems are no-analog systems that have passed a threshold and cannot be restored to a previous stage (Ahern 2016, Collier and Devitt 2016). "They are the product of the interacting forces of urbanization, globalization and climate change, and are made up of organisms that have been brought together by the elimination or neutralization of barriers that had kept them separated for millions of years" (Del Tredici 2014).

These new ecosystems apparently have no parallel in the natural environment and are becoming the dominant habitats on the face of the Earth. According to Perring and Ellis (2013), the extent of novel ecosystems on the planet is around $40 \%$. Mild climates are the most susceptible ones, such as north-western Portugal and Galicia (Spain), with no limiting factors, giving way to vast areas of pseudo-spontaneous woodlands of 
Eucalyptus, Accacia, Robinia, Pittosporum, Aillanthus, along with new grassland communities dominated by Cortaderia selloana and the impenetrable scrubs of Hakea sericea.

Although we do not know how these novel ecosystems will evolve in the future, they may be as valuable as historical ecosystems, namely regarding their social-ecological resilience and as potential providers of ecosystem services (Collier et al. 2016).

These overwhelming issues require a fresh look in order to develop combined approaches to guarantee: (1) the conservation of long term evolving ecosystems; (2) the sustainability of human dependent ecosystems; and the (3) integration of novel ecosystems with old ecosystems. We must keep in mind native species conservation and their articulation with non-invasive exotic species and the benefits of existing and new green structures to mitigate climate change, desertification, poverty and other environmental disruptions.

\section{THE WILD GARDEN, OR NATURE AT YOUR DOORSTEP}

Even small-scale projects can change your perception, your knowledge, your life. The practice of nature stimulation can be pursued at any scale of intervention, producing new landscapes of proximity with high biodiversity levels and a semi-wild character, which is aesthetically stimulating, informative and achievable in five to ten years. Since 2008-2009 such an experience is being developed on the grounds of the School of Sciences of the University of Porto
(Figs. 1, 2) aiming at the creation of a "wild garden" in spare spaces adjacent to the administrative and biology buildings (Farinha-Marques et al. 2016).

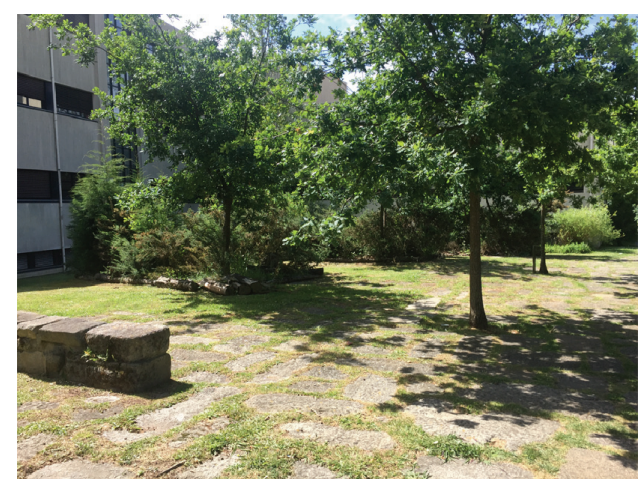

FIGURE 1. FCUP “wild” garden, late June 2017. The north facing "wet-wild" with its oak stands (Quercus robur), regenerating Ulex europaeus patches and old stone paving (rescued from a demolished building)

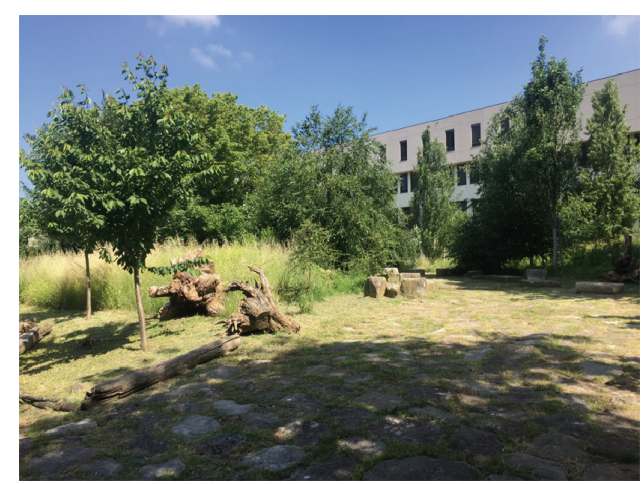

FIGURE 2. FCUP “wild garden”, late June 2017. The south facing "dry-wild" with its developing mixed woodland and tall meadow just before the summer mowing. Several pioneer species (Poplar sp., Betula pubescens celtiberica, Prunus sp. and Fraxinus angustifolia) already followed by climax species such as Quercus suber and Quercus faginea

Why "wild"? Because "wild" is becoming rare and precious, and gardens are the places to conserve rare and pre- 
cious beings. The project is inspired by a wide variety of concepts ranging from landscape integration, restoration ecology, urban biodiversity, assisted natural regeneration, re-wilding, planting autochthonous species, the reusing and recycling of materials, art installations, "wild" aesthetics, learning by doing, and participatory design and management. All of them have been combined to produce a unique experience of learning through nature cultivation and people's interaction in outdoor spaces, left from construction and without particular appeal or conditions, soil improvement or fancy materials. The main strategy relies on sustainable and adaptable design and people's involvement, bringing together different interests: students and teachers; rescued and new materials; natives and exotics; vigorous and less vigorous plants; irrigation and drought; plans and improvisations; science and art; all together in a trial of "making it possible". Over the years It has become a small-scale landscape laboratory that can be constantly surveyed, monitored and experienced by the academic community and the general public. During its short life it has been a place for learning and practising, particularly in landscape architecture and urban ecology. With less than a hectare, distributed among several spaces, some of them not connected with each other, it is becoming another example of a "new nature" created from scratch by people in a relatively short period of time. The experience of being a low cost/low energy landscape project using native species with the inclusion of some existing exotic species became its focal approach. Then the adoption of an experimental type of management (semi-naturalistic management) trying to achieve the maximum ecological and aesthetical result with the minimum intervention is also central (we must say that this was not always satisfactory and emphasizing its true experimental character). A "cut/no cut" method, allowed: to test the mowing regime for wildflower meadows, created opportunities for "supervised" natural succession plots where native scrub develops together with aggressive invasive woody species; and the confirmation of the need to adapt the natural/wild systems to human use in order to make them possible in the urban context. These outputs are not new. Most pre-industrial humans were well aware of them; however, with the increasing distance between ourselves and the biophysical realities and activities, it is very relevant to make them visible and close to our overwhelming urban life. Let us therefore bring some hope to our perilous time. Let's be open to interacting with nature and constantly learning by perceiving and experiencing its multitude of situations. We must try to cultivate it and engage others in the process. Let's share, participate, distribute and inform. Let's respect wilderness, its beauty and uniqueness. Let's give space to others, the big tree, the big herbivore or the big predator. Let's make landscapes with nature in mind.

\section{REFERENCES}

AHERN J. 2016: Novel Urban Ecosystems: Concepts, Definitions and a Strategy to Support Urban Sustainability and Resilience. Landsc. Arch. Front. 4 (1): 10-21.

BRATMAN G.N., DAILY G.C., LEVY B.J., GROSS J.J. 2015: The benefits of nature 
experience: Improved affect and cognition. Landsc. Urban Plan. 138: 41-50.

Bulletin of the Atomic Scientists 2017: It is two and a half minutes to midnight. 2017 Doomsday Clock Statement. Retrieved from: https://thebulletin.org/sites/default/ files/Final $\% 202017 \% 20$ Clock $\% 20$ State ment.pdf.

CHOMSKY N. 2017: Racing to the Precipice: Global Climate, Political Climate. Starr Forum of the MIT Center for International Studies. Retrieved from: https:// www.youtube.com/watch? $\mathrm{v}=\mathrm{TK} 0 \mathrm{R}$ 06zOOY\&t=2796s.

COLLÉONYA., PRÉVOT A., JALME M.S., CLAYTON S. 2017: What kind of landscape management can counteract the extinction of experience? Landsc. Urban Plan. 159: 23-31. doi: 10.1016/j.landurbplan.2016.11.010

COLLIER M.J., DEVITT C. 2016: Novel ecosystems: Challenges and opportunities for the Anthropocene. The Anthropocene Review 3 (3): 231-242.

Del TREDICI P. 2007: The Role of Horticulture in a Changing World. In: M. Conan, W.J. Kress (Eds.) Botanical Progress, Horticultural Innovation, and Cultural Changes. Dumbarton Oaks, Washington, DC: 259-264.

Del TREDICI P. 2014: The Flora of the Future. Places Journal. https://doi. org/10.22269/140417

DONIHUE C.M., LAMBERT M.R. 2015: Adaptive evolution in urban ecosystems. AMBIO 44: 194-203.

ELLIS E.C. 2011: Anthropogenic transformation of the terrestrial biosphere. Phil. Trans. R. Soc. A 369: 1010-1035. doi: 10.1098/rsta.2010.0331

ELLIS E.C. 2015: Ecology in an anthropogenic biosphere. Ecol. Monogr. 85 (3): 287-331. doi: 10.1890/14-2274.1

ELLIS E.C., HAFF P.K. 2009: Earth science in the Anthropocene: new epoch, new paradigm, new responsibilities. EOS Transact. 90: 473.
FARINHA-MARQUES P., FERNANDES C., GUILHERME F. 2016: Experimental Design and Maintenance of FCUP "Wild Garden": Researching and Learning Urban Nature. In: P. Bauer, M. Collender, L.K. Jakob, M., Bonnelame, P. Petschek, D. Siegrist, C. Tschumi (Eds.) Bridging the Gap. Peer reviewed proceedings of European Council of Landscape Architecture Schools 2016 Conference, HRS Hochshule fur Technick, Rapperswil, 11-14.09 .2016 .HSR Hochschule fur Technik Rapperswil, Rapperswil: 465-468.

GRIMM N.B., FAETH S.H., GOLUBIEWSKI N.E., REDMAN C.L., WU J.G., BAI X.M., BRIGGS J.M. 2008: Global change and the ecology of cities. Science 319 (5864): 756-760. doi: 10.1126/science. 1150195

KAPLAN S. 1995: The restorative benefits of nature: Toward an integrative framework. J. Environ. Psych. 15 (3): 169-182.

KOWARIK I. 2011: Novel urban ecosystems, biodiversity, and conservation. Environ. Pollut. 159: 1974-1983.

KÜHN I., BRANDL R., KLOTZ S. 2004: The flora of German cities is naturally species rich. Evolut. Ecol. Res. 6: 749-764.

KUO F.E. 2003: The role of arboriculture in a healthy social ecology. J. Arboricult. 29: 148-155.

LOUV R. 2010: Do Our Kids Have Nature-Deficit Disorder? Health Learn. 67 (4): 24-30.

Millennium Ecosystem Assessment 2005: Ecosystems and Human Well-being. A Framework for Assessment. Island Press, Washington, DC.

MILLER J.R., HOBBS R.J. 2002: Conservation where people live and work. Conserv. Biol. 16 (2): 330-337. http://dx.doi. org/10.1046/j.1523-1739. 2002.00420.x

SOGA M., GASTON K.J. 2016: Extinction of experience: The loss of human-nature interactions. Front. Ecol. Environ. 14 (2): 94-101. http://dx. doi.org/10.1002/ fee. 1225 
United Nations Population Division 2016. The World's Cities in 2016.

VELARDE M.D., FRY G., TVEIT M. 2007: Health effects of viewing landscapes - Landscape types in environmental psychology. Urban Forestry \& Urban Greening 6: 199-212. https://doi.org/10.1016/ j.ufug.2007.07.001

Streszczenie: Niezrównoważone, odrestaurowane i nowe ekosystemy - koncepcje i praktyka stanowiace wyzwanie dla planowania krajobra$z u$, projektowania i zarzqdzania $w$ XXI wieku. Od czasów XVIII-wiecznej rewolucji przemysłowej populacja ludzka szybko rośnie (około 7,5 miliarda ludzi w 2017 roku), głęboko zmienia wszystkie ekosystemy Ziemi i w coraz większym stopniu koncentruje się w miastach (54\% w 2014 roku), tworząc rozległe tereny metropolitarne. Tak duże liczby wymuszają szybkie zmiany metabolizmu biosfery, wynikające $\mathrm{z}$ wylesienia, uszczuplenia naturalnych zasobów, zanieczyszczenia, globalnego ocieplenia, pustynnienia, niekontrolowanej zabudowy i utraty różnorodności biologicznej. Rezultaty badań pokazują ogromne obszary ogołoconych, nudnych i ubogich krajobrazów, niezdolnych do wyżywienia swoich populacji, zmuszających je do migracji, do głodowania lub walki. Środki konserwacji koncentrowały się na odległych lub mniej zaludnionych obszarach, szczególnie tych, które zachowały bardzo wysoką jakość przyrodnicza, wiele walorów estetycznych, ważne gatunki dzikich zwierząt lub przedprzemysłowy wiejski charakter. Kilka strategii restauracji zostało wdrożonych, szczególnie w krajach rozwiniętych, aby ratować zdegradowane krajobrazy. To doprowadziło do powstania różnej skali „,zielonych" struktur, takich jak: rezerwaty przyrody, pasy zieleni, zielone korytarze, błękitna i zielona infrastruktura, miejsca i krajobrazy dziedzictwa kulturowego oraz miejskie tereny zieleni. Współczesne przepływy ludności doprowadziły do przemieszczenia gatunków przez oceany $i$ kontynenty, zwiększając nagłą kolonizację i natychmiastową zmianę lokalnych ekosystemów, które dawniej ewoluowały przez długi czas. Ostatnio niektóre z tych asamblaży gatunków zyskały określenie nowych ekosystemów: powstałe w wyniku działalności człowieka, samowystarczalne asamblaże „egzotycznych" i rodzimych gatunków w szczególnych biofizycznych kontekstach, z tendencją do dominacji i przewagi „egzotyki” nad lokalnymi gatunkami. Te nowe ekosystemy pozornie nie są podobne do naturalnego środowiska i stają się dominującymi habitatami na Ziemi. Te istotne kwestie wymagają świeżego spojrzenia dla wypracowania łącznego i systemowego podejścia do konserwacji długo ewoluujących naturalnych ekosystemów, zrównoważonego rozwoju ekosystemów zależnych od człowieka i integracji nowych ekosystemów ze starymi. Zaangażowanie każdego jest cenne, aby dzielić się pomysłami i działaniami integrującymi zmianę, a także gwarantującymi bardzo dużą różnorodność biologiczną dostępność zasobów naturalnych i terenów przyrodniczych w przyszłości. Nasza globalna świadomość powinna aktywować programy i praktykę w zakresie planowania miejscowego, projektowania i zarządzania, aby sprawdzić wiedzę, stawić czoło biedzie oraz poprawić jakość i godność życia. To kwestia życia lub śmierci a... ŻYCIE JEST WAŻNE!

Slowa kluczowe: przeludnienie, nowe ekosystemy, nowe krajobrazy, globalna świadomość, lokalne działanie

MS received: 17.10.2017

MS accepted: 03.04.2018

Authors' address:

Paulo Farinha-Marques

Faculty of Sciences

University of Porto

Rua do Campo Alegre 1021/1055

4169-007 Porto

Portugal

e-mail: pfmarque@fc.up.pt 